\title{
Quality Evaluation of Complete Feed with Ramie Waste Added With Different Protein Source in Nutrient Composition and Ensilage Parameter
}

\author{
Emmy Susanti ${ }^{1)^{*}}$, Ali Agus $^{2)}$, Y Yuni Suranindyah ${ }^{2)}$ and FM Suhartati ${ }^{1)}$ \\ ${ }^{1)}$ Faculty of Animal Science, Jenderal Soedirman University, Dr. Soeparno Street No. 60, PO Box 110, \\ Purwokerto 53123, Central Java, Indonesia \\ ${ }^{2)}$ Faculty of Animal Science, Gajah Mada University, Jl. Fauna No. 3, Bulaksumur, Yogyakarta, Indonesia \\ *Corresponding author email: emmy_susanti@yahoo.co.id
}

\begin{abstract}
The objective of this research was to evaluate the effect of ensilage technology (with and without ensilage) and protein sources (plant and animal) in complete feed with ramie-waste on nutrient composition and ensilage parameter. Ensilage process decreased significantly dry matter (DM), organic matter (OM) and neutral detergent fiber (NDF), but it increased ensilage parameter i.e. acetate acid $\left(C_{2}\right)$, propionic acid $\left(C_{3}\right)$, butyric acid $\left(\mathrm{C}_{4}\right)$, lactic acid (LA), and decreased pH. It also had non-significant effect on crude fibre (CP), acid detergent fiber (ADF) and ammonia $\left(\mathrm{NH}_{3}-\mathrm{N}\right)$. Animal protein source in silage making decreased nutrient composition i.e. $\mathrm{OM}$ and $\mathrm{CP}$ and ensilage parameter i.e. $\mathrm{C}_{2}$, but it increased $\mathrm{NH}_{3}-\mathrm{N}$. Interaction between ensilage treatment and protein sources affected $\mathrm{CP}$ and pH also ensilage parameter of $\mathrm{C}_{2}$ and $\mathrm{C}_{3}$. In conclusion, plant protein used in silage of complete feed with ramie waste was better than animal protein, despite that both ensilage were not better due to $\mathrm{pH}$ over 4.5.
\end{abstract}

Key words: ramie, ensilage technology, protein source, nutrient composition, ensilage parameter

Abstrak. Penelitian ini bertujuan mengevaluasi pengaruh teknologi ensilage (dengan dan tanpa ensilage) dan sumber protein (nabati dan hewani) pada complete feed menggunakan limbah rami terhadap komposisi nutrien dan parameter ensilage. Perlakuan teknologi ensilage menurunkan komposisi nutrien pada bahan kering (BK), bahan organik (BO) dan neutral detergent fiber (NDF, meningkatkan kuantitas parameter ensilage pada asam asetat $\left(C_{2}\right)$, asam propionat $\left(C_{3}\right)$, asam butirat $\left(C_{4}\right)$ dan asam laktat $(L A)$ dan menurunkan $\mathrm{pH}$ serta tidak nyata pada protein kasar (PK), acid detergent fiber (ADF) dan ammonia $\left(\mathrm{NH}_{3}-\mathrm{N}\right)$. Perlakuan sumber protein menurunkan nutrien $\mathrm{BO}$ dan $\mathrm{PK}$ dan $\mathrm{C}_{2}$ serta meningkatkan konsentrasi $\mathrm{NH}_{3}-\mathrm{N}$ secara sangat nyata pada complete feed dengan protein hewani. Interaksi kedua perlakuan berpengaruh pada PK dan pH serta $\mathrm{C}_{2}$ dan $\mathrm{C}_{3}$. Kesimpulannya adalah penggunaan protein nabati pada silage complete feed menggunakan limbah rami lebih baik dari pada yang menggunakan protein hewani meskipun kedua jenis silage tidak lebih baik karena $\mathrm{pH}$ lebih dari $4,5$.

Kata kunci: rami, teknologi ensilage, sumber protein, komposisi nutrien, parameter ensilage

\section{Introduction}

Factors determining farming success are breed, feed and management. Feed is the most costly factors, worsened by the fluctuating quality and quantity supply over the year. The fluttering feed supply can be solved by abundant green feed preservation. Simple and inexpensive preservation technology is ensilage, which in complete feed is to increase its quality for durable storage (Wongnen et al., 2009), and to improve digestibility of dry matter (DM), organic matter (OM), crude fiber
(CF) and non-structural carbohydrate (Vasupen et al., 2005; 2006) due to lactic acid growth. Lactic acid will cause lower $\mathrm{pH}$, discontinue enzymatic activity, the process then will preserve silage.

Ramie (Boehmeria nivea L. Goudich) is fiberproducing plant. The green waste reaches 93$97 \%$ of total plant production (Gabbi et al., 2004), consisting of leaves and decorticated stems. Fresh ramie leaves waste reaches 3000 $\mathrm{kg} / \mathrm{ha} /$ harvest (Liu Li-Jun et al., 2012) with 22\% crude protein (CP) (Yongsheng et al., 2014) 
while decorticated stem waste is 9600 $\mathrm{kg} / \mathrm{ha} /$ harvest (Liu Li-Jun et al., 2012). The nutrient compositions of ramie leaf contain 91.42\% DM, 21.00\% CP, $4.10 \% \mathrm{EE}, 20.87 \% \mathrm{CF}$ and $45.45 \%$ total carbohydrate (Conto et al., 2011). Crude protein of ramie leaves and crude fiber of ramie stem are potential component for ruminant complete feed. Ramie leave waste has low concentraton of $(\mathrm{P})$, cuprum $(\mathrm{Cu})$ and methionine that is $0.16 \%, 0.69 \%$ and $1.29 \mathrm{~g} / 100 \mathrm{~g}$, respectively (Conto et al., 2011), while waxy residue is found on ramie stem. Ramie is harvested every 50-60 days over the year (Subandi, 2012).

Complete feed is composed of all essential nutrients either from concentrate or green feed (Tisch, 2006). The utilization of ramie waste as the main component of complete feed requires additional source of nutrient supply, such as highly digestible energy source, protein, vitamin and mineral, to meet the criteria of complete feed. The plant protein sources which can be added in the complete feed are soybean and soybean meal, while the animal protein source is fish meal. Different protein source and feed compositions were used due to different nutrient composition that affected the nutrient composition of complete feed with ramie waste.

This objective of the experiment was to evaluate the effects of ensilage technology (with and without ensilage process), the protein sources (plant protein and animal protein) and the interactions between two treatments in complete feed with ramie waste on nutrient composition and ensilage parameters.

\section{Materials and Methods}

Research was conducted from November to December 2012 in Laboratory of Feedstuff Study, Animal Science Faculty, Jenderal Soedirman University, Purwokerto. Complete feed was composed to fulfill nutrient demand of weaned kids of Etawah cross breed goat (TDN $65.00 \%$ dan CP 18.20\%) (Sharifi et al.,
2013; Assan, 2015). Feed components were obtained from Banyumas regency except for fish meal, soybean meal, ground soybean and vitamin-mineral mix were collected from Yogyakarta. Silage container (silo) was made of polyethilene, other instruments were chopper, vacuum pump, scale, oven and nutrient feed analysis kit. The analysis of DM, OM and CP followed AOAC (1994), guidelines while analysis of NDF and ADF was subject to Zhao et al. (2011) and $\mathrm{NH}_{3}-\mathrm{N}$ was analyzed with Lowrie methods. Analysis of $\mathrm{C}_{2}$ (acetic acid), $\mathrm{C}_{3}$ (propionic acid), $C_{4}$ (butyric acid) and (LA) lactic acid was conducted using Chromatography (Nigam and Ayyagari, 2007).

In current research the main components of complete feed consisted of ramie leaves and stalks from harvest residue. Leaves were made wilted for \pm 12 hours and stems were drained for \pm 12 hours. This process for stalks was known as decortications (to separate ramie fibers along with water purge). The components, well-mixed by combining the least and the most amount were weighed per $2,5 \mathrm{~kg}$ and stored in 20 double polyethilen plastic bags according to treatment unit (formula and feed composition is presented in Table 1). The separately mixed ramie leaves and stems were combined with the homogenous concentrate. To make anaerobic condition for ensilage process, vacuum pump was used to minimize oxygen content in the plastic bag. The 10 units of the ensilaged complete feed were stored for 21 days in room temperature. While the other non-ensilage 10 treatment units were directly analyzed for nutrient composition and ensilage parameter.

The statistical analysis was designed using $2 \times 2$ factorial design (CRD) with 5 replicates. Four treatments were $\mathrm{CF}_{0} \mathrm{~N}$ : non-ensilage complete feed with plant protein; $\mathrm{CF}_{0} \mathrm{H}$ : nonensilage complete feed with animal protein; $\mathrm{CF}_{1} \mathrm{~N}$ : ensilage complete feed with plant protein source; and $\mathrm{CF}_{1} \mathrm{H}$ : ensilage complete feed with 
Emmy Susanti et al/Animal Production. 17(1):35-41, January 2015

Accredited by DGHE No. 81/DIKTI/Kep./2011. ISSN 1411-2027

Table 1. Formula and nutrient composition of complete feed

\begin{tabular}{|c|c|c|c|c|}
\hline \multirow[b]{2}{*}{ Composition } & $\mathrm{CF}_{0} \mathrm{~N}$ & $\mathrm{CF}_{1} \mathrm{~N}$ & $\mathrm{CF}_{0} \mathrm{H}$ & $\mathrm{CF}_{1} \mathrm{H}$ \\
\hline & \multicolumn{4}{|c|}{$\%$} \\
\hline Ramie leaves & 13.5 & 13.5 & 13.5 & 13.5 \\
\hline Ramie stems & 16.5 & 16.5 & 16.5 & 16.5 \\
\hline Dried cassava (gaplek) & 10 & 10 & 10 & 10 \\
\hline Tapioca by-products (onggok) & 10 & 10 & 10 & 10 \\
\hline Rice bran & 9.4 & 9.4 & 14.95 & 14.95 \\
\hline Pollard & 9 & 9 & 9 & 9 \\
\hline Soy bean meal & 10.5 & 10.5 & - & - \\
\hline Ground soy bean & 8.8 & $8 ., 8$ & - & - \\
\hline Fish meal & - & - & 13.75 & 13.75 \\
\hline Molases & 10 & 10 & 10 & 10 \\
\hline Urea & 0.3 & 0.3 & 0.3 & 0.3 \\
\hline Salt & 0.5 & 0.5 & 0.5 & 0.5 \\
\hline Lime & 0.5 & 0.5 & 0.5 & 0.5 \\
\hline Mineral+Vitamin & 1 & 1 & 1 & 1 \\
\hline Total & 100 & 100 & 100 & 100 \\
\hline \multicolumn{5}{|l|}{ Chemical composition* } \\
\hline Ash ( \% DM) & 10.42 & 9.50 & 13.53 & 11.25 \\
\hline Fat ( \% DM) & 1.93 & 2.51 & 3.31 & 3.42 \\
\hline Crude fiber ( \% DM) & 19. 59 & 13.46 & 19.91 & 15.65 \\
\hline NFE ( \% DM) & 48.18 & 52.99 & 41.12 & 49.62 \\
\hline Crude protein $(\% \mathrm{DM})^{1}$ & 19.88 & 21.54 & 22.13 & 20.07 \\
\hline $\operatorname{TDN}(\% \mathrm{DM})^{1}$ & 70.01 & 70.01 & 65.74 & 65.74 \\
\hline
\end{tabular}

*)Calculation was based on table (Hartadi et al., 2005) and laboratory analysis

${ }^{1}$ )Nutrient requirement of weaned dairy goat was $18.20 \%$ crude protein and $65.00 \%$ TDN (Sharifi et al., 2013).

$\mathrm{CF}_{0} \mathrm{~N}$ : complete feed with plant protein without ensilage. $\mathrm{CF}_{1} \mathrm{~N}$ : ensilaged complete feed with plant protein source. $\mathrm{CF}_{0} \mathrm{H}$ : complete feed with animal protein without ensilage. $\mathrm{CF}_{1} \mathrm{H}$ : ensilaged complete feed with animal protein

animal protein. The obtained data were subject to analysis of variance according to General Linear Models (GLM). Variables showing significant effect were subject to Honestly Significant Difference test (Steel and Torrie, 2007). The observed parameter was nutrient compositions namely DM, OM, CP (AOAC, 1994), NDF and ADF (Van Soest, 1982), while ensilage parameter variables consisted of $\mathrm{pH}$, partial VFA level (acetic acid, propionic acid, and butyric acid), lactic acid (Nigam and Ayyagari, 2007), $\mathrm{NH}_{3}-\mathrm{N}$ (Lowry methode) and physical quality comprising color, aroma, texture and the existence of mold.

\section{Results and Discussion}

\section{Ensilage Technology}

Nutrient Composition. Ensilage treatment on complete feed with ramie waste significantly affected DM, OM and NDF $(P<0.01)$. The average DM in non-ensilage complete feed with ramie waste was $47.06 \pm 1.85 \%\left(\mathrm{CF}_{0} \mathrm{~N}\right)$ and $47.13 \pm 1.92 \%\left(\mathrm{CF}_{0} \mathrm{H}\right)$ higher than that with ensilage namely $44.36 \pm 1.87 \% \quad\left(\mathrm{CF}_{1} \mathrm{~N}\right)$ and 43.59 $\pm 1.60\left(\mathrm{CF}_{1} \mathrm{H}\right) \quad(\mathrm{P}<0.01)$ (Table 2). DM loss during ensilage process was due to microbial activity that used nutrient in complete feed for energy and nitrogen source. Early ensilage stage was related to enzymatic activity of plant cell (Owen et al., 2002), that used carbohydrates, particularly glucose and fructose with oxygen trapped in silage (Shao et al., 2005). Wongnen et al. (2009) reported DM decrease in ensilage process in complete feed containing whole cottonseed, from $63.87 \%$ (non-ensilage complete feed) to $61.9 \%$ (ensilage complete feed). Organic matter in non-ensilage complete feed with ramie waste was $89.16 \pm 1.32 \% \quad\left(\mathrm{CF}_{0} \mathrm{~N}\right)$ and $86.15 \pm 0.96 \%$ $\left(\mathrm{CF}_{0} \mathrm{H}\right)$ higher than that with ensilage, namely 
Table 2. Chemical composition of complete feed with ramie waste with ensilage and without ensilage with different protein sources (\%DM).

\begin{tabular}{|c|c|c|c|c|}
\hline Nutrient & Protein source & $\mathrm{CF}_{0}$ & $\mathrm{CF}_{1}$ & Interaction \\
\hline \multirow[t]{2}{*}{$\mathrm{DM}, \%$} & $\mathrm{~N}$ & $47.06 \pm 1.85^{\mathrm{a}}$ & $44.36 \pm 1.87^{b}$ & NS \\
\hline & $\mathrm{H}$ & $47.13 \pm 1.92^{\mathrm{a}}$ & $43.59 \pm 1.60^{b}$ & \\
\hline \multirow[t]{2}{*}{ OM, \% } & $\mathrm{N}$ & $89.16 \pm 1.32^{\mathrm{ce}}$ & $85.33 \pm 2.87^{\mathrm{de}}$ & NS \\
\hline & $\mathrm{H}$ & $86.15 \pm 0.96^{c f}$ & $83.66 \pm 0.59^{\mathrm{df}}$ & \\
\hline \multirow[t]{2}{*}{$\mathrm{CP}, \%$} & $\mathrm{~N}$ & $18.51 \pm 0.97^{\mathrm{g}}$ & $18.83 \pm 0.98^{\mathrm{g}}$ & $\mathrm{S}$ \\
\hline & $\mathrm{H}$ & $17.88 \pm 0.50^{\mathrm{h}}$ & $16.19 \pm 0.88^{h}$ & \\
\hline \multirow[t]{2}{*}{ NDF, \% } & $\mathrm{N}$ & $36.71 \pm 1.90^{i}$ & $31.24 \pm 2.83^{j}$ & NS \\
\hline & $\mathrm{H}$ & $34.56 \pm 2.13^{i}$ & $30.23 \pm 4.98^{j}$ & \\
\hline \multirow[t]{2}{*}{ ADF, $\%$} & $\mathrm{~N}$ & $19.29 \pm 2.37$ & $21.50 \pm 1.63$ & NS \\
\hline & $\mathrm{H}$ & $20.23 \pm 2.66$ & $20.11 \pm 1.02$ & \\
\hline
\end{tabular}

${ }^{\mathrm{a}-\mathrm{j}}$ : values bearing different superscript within row or column are significant differences $(P<0.01)$.

DM: dry matter; OM: organic matter; CP: crude protein; NDF: neutral detergent fiber; ADF: acid detergent fiber. $\mathrm{CF}_{0}$ : non-ensilage ramie waste-based complete feed; $\mathrm{CF}_{1}$ : non-ensilage ramie waste-based complete feed; $\mathrm{N}$ : ramie waste-based complete feed with plant protein; $\mathrm{H}$ : ramie waste-based complete feed with animal protein

$85.33 \pm 2.87 \%\left(\mathrm{CF}_{1} \mathrm{~N}\right)$ and $83.66 \pm 0.59 \%\left(\mathrm{CF}_{1} \mathrm{H}\right)$ $(\mathrm{P}<0.01)$. Organic matter, particularly carbohydrate and protein, was nutrient for microbial activity. Conto et al. (2011), reported that $\mathrm{OM}$ content of king grass decreased from $88,83 \%$ to $82.37 \%$ after ensilage. NDF percentage in non-ensilage complete feed with ramie waste was $36.71 \pm 1.9 \%\left(\mathrm{CF}_{0} \mathrm{~N}\right)$ and $34.56 \pm 2.13 \%\left(\mathrm{CF}_{0} \mathrm{H}\right)$, higher than that with ensilage, namely $31.24 \pm 2.83 \% \quad\left(\mathrm{CF}_{1} \mathrm{~N}\right)$ and $30.23 \pm 4.98 \%\left(\mathrm{CF}_{1} \mathrm{H}\right)(\mathrm{P}<0.01)$. Ensilage process lowered $\mathrm{pH}$, while the optimal $\mathrm{pH}$ for fibrinolytic activity ranged 5-7. The changes of $\mathrm{pH}$ during ensilage was down from 7 to 5 , which was the optimal $\mathrm{pH}$ range for fibrinolytic activity. Fiber decrease in silage was related to proteolysis and fibrinolytic activity of microbes and plant (Kung et al., 2000; Nadeau et al., 2000).

Ensilage Parameter. Complete feed with ramie waste without ensilage indicated lower average of $C_{2}, C_{3}, C_{4}$ and LA than that with ensilage; contrastively, complete feed with ramie waste without ensilage showed higher $\mathrm{pH}$ average than that with ensilage $(P<0.01)$. Acetic acid in complete feed with ramie waste without ensilage was $2.08 \pm 0.94 \mathrm{mMol}\left(\mathrm{CF}_{0} \mathrm{~N}\right)$ and $1.64 \pm 0.33 \mathrm{mMol}\left(\mathrm{CF}_{0} \mathrm{H}\right)$, lower than that with ensilage, namely $23.22 \pm 11.23 \mathrm{mMol}\left(\mathrm{CF}_{1} \mathrm{~N}\right)$ and $3.99 \pm 2.76 \mathrm{mMol}\left(\mathrm{CF}_{1} \mathrm{H}\right)(\mathrm{P}<0.01)$. The increased $\mathrm{C}_{2}$ concentration was in result of the decreased NDF concentration of ensilaged complete feed with ramie waste. It was due to $C_{2}$ was the product of fiber fermentation. Santoso and Hariadi (2008), reported their research on ensiled $P$. purpureum that produced $43.4 \mathrm{mM}$ of acetic acid $\left(C_{2}\right)$. The average of $C_{3}$ in complete feed with ramie waste without ensilage was $15.20 \pm 3.39 \mathrm{mMol}\left(\mathrm{CF}_{0} \mathrm{~N}\right)$ and $10.77 \pm 3.61 \mathrm{mMol}\left(\mathrm{CF}_{0} \mathrm{H}\right)$, or lower than the ensilaged complete feed $\mathrm{CF}_{1} \mathrm{~N}$ and $\mathrm{CF}_{1} \mathrm{H}$, namely $15.54 \pm 3.03 \mathrm{mMol}$ and $26.51 \pm 4.22 \mathrm{mMol}$, respectively $(P<0.01)$. The increased $C_{3}$ concentration was due to WSC degradation in complete feed with ramie waste. This was because the activity of amylolytic bacteria used WSC to produced $C_{3}$. The concentration of $C_{3}$ in $P$. purpureum silage was $15,8 \mathrm{mM}$ (Santoso and Hariadi, 2008). The average of $\mathrm{C}_{4}$ complete feed with ramie waste without ensilage was $0.99 \pm 0.05 \mathrm{mMol}\left(\mathrm{CF}_{0} \mathrm{~N}\right)$ and $1.01 \pm 0.17 \mathrm{mMol}$ $\left(\mathrm{CF}_{0} \mathrm{H}\right)$. Those were lower than ensilaged complete feed, namely $1.64 \pm 0.55 \mathrm{mMol}$ and $2.93 \pm 0.44 \mathrm{mMol}$, respectively for $\mathrm{CF}_{1} \mathrm{~N}$ and $\mathrm{CF}_{1} \mathrm{H}(\mathrm{P}<0.01)$. The concentration of $\mathrm{C}_{4}$ (butiric acid) in complete feed with ramie-waste was lower than that in silage of $P$ purpureum, 7.3 
mMol (Santoso and Hariadi, 2008). The lower concentration of $\mathrm{C}_{4}$ in complete feed with ramie waste indicated the beginning of putrefaction. Average LA in complete feed with ramie waste without ensilage was $365.09 \pm 101.52 \mathrm{mg} / 100 \mathrm{~g}$ $\left(\mathrm{CF}_{0} \mathrm{~N}\right)$ and $263.36 \pm 75.56 \mathrm{mg} / 100 \mathrm{~g}\left(\mathrm{CF}_{0} \mathrm{H}\right)$, significantly lower than 1565.38 \pm 551.61 $\mathrm{mg} / 100 \mathrm{~g}\left(\mathrm{CF}_{1} \mathrm{~N}\right)$ and $1751.32 \pm 275.48 \mathrm{mg} / 100 \mathrm{~g}$ $\left(\mathrm{CF}_{1} \mathrm{H}\right)$ with ensilage $(\mathrm{P}<0.01)$. Concentration of LA increase in ensilaged complete feed with ramie waste demonstrated that the complete feed was the optimal media for lactic acidproducing bacteria during ensilage process. It was followed by decreasing OM average percentage (from $89.16-86.15 \%$ to 83.66 $85.33 \%$ ) and $\mathrm{pH}$ decrease (from $6.77-5.99$ to 4.99 - 4.61). LA concentration in ball-shaped complete feed was $1040 \mathrm{mg} / 100 \mathrm{~g} \mathrm{DM}$, and increased to $3800 \mathrm{~g} / 100 \mathrm{~g}$ DM after 30 day ensilage. The $\mathrm{pH}$ of ball-shaped complete feed decreased from 5.35 to 4.65 , and DM loss was $43 \mathrm{~g} / \mathrm{kg}$ DM with 40:60 ratio of green feed: concentrate (Wang et al., 2010). Average pH complete feed with ramie waste without ensilage was $5.99 \pm 0.36\left(\mathrm{CF}_{0} \mathrm{~N}\right)$ and $6.77 \pm 0.55$ $\left(\mathrm{CF}_{0} \mathrm{H}\right)$, higher than that with ensilage, namely $4.99 \pm 0.36\left(\mathrm{CF}_{1} \mathrm{~N}\right)$ and $4.61 \pm 0.09\left(\mathrm{CF}_{1} \mathrm{H}\right)(\mathrm{P}<0.01)$. $\mathrm{pH}$ decreased in complete feed with ramie waste was linear to the increasing concentration of $C_{2}, C_{3}, C_{4}$ or $L A$ after ensilage. $\mathrm{pH}$ decreased during ensilage of the ball-shaped complete feed, but the concentration of $C_{2}, C_{3}$, lactic acid and ammonia- $\mathrm{N}$ increased (Wang et al., 2010).

\section{Protein Source}

Nutrient Composition. The treatments of different sources of protein (plant protein and animal protein) in complete feed with ramie decreased $O M$ and $C P(P<0.01)$. Organic matter of complete feed with ramie waste with plant protein as in $\mathrm{CF}_{0} \mathrm{~N}$ and $\mathrm{CF}_{1} \mathrm{~N}$ was $89.16 \pm 1.32 \%$ and $85.33 \pm 2.87 \%$, respectively, significantly different from that with animal protein as in $\mathrm{CF}_{0} \mathrm{H}$ and $\mathrm{CF}_{1} \mathrm{H}$, namely $86.15 \pm 0.96 \%$ and $83.66 \pm 0.59 \%$, respectively $(P<0.01)$. Proximate analysis on OM of complete feed with animal protein (fishmeal) was lower than that with plant protein (feed grade soybean + soybean meal). Ensilaged complete feed with fish meal had the lowest OM percentage. Both caused complete feed with animal protein had lower percentage than the other. Crude protein percentage of complete feed with ramie waste and with plant protein as in $\mathrm{CF}_{0} \mathrm{~N}$ and $\mathrm{CF}_{1} \mathrm{~N}$ was $18.51 \pm 0.97 \%$ and $18.83 \pm 0.98 \%$, respectively, or significantly higher than that of animal protein in $\mathrm{CF}_{0} \mathrm{H}$ and $\mathrm{CF}_{1} \mathrm{H}$, namely $17.88 \pm 0.50 \%$ and $16.19 \pm 0.88 \%$, respectively $(P<0.01)$. The decreased of CP was caused by deamination of protein (putrefaction) and followed by the increased $\mathrm{NH}_{3}-\mathrm{N}$ concentration from 0.31-0.42 $\mathrm{mg} / 100 \mathrm{ml}$ to $0.038-0.045 \mathrm{mg} / 100 \mathrm{ml}$. Santoso and Hariadi (2008), reported that ensilaged $P$. purpureum produced $\mathrm{NH}_{3}-\mathrm{H} 16$ $\mathrm{mg} / 100 \mathrm{ml}$.

Ensilage Parameter. Protein source affected an increase in concentrations of $\mathrm{C}_{2}$ and $\mathrm{NH}_{3}-\mathrm{N}$ $(P<0.01)$. Concentration of $C_{2}$ in complete feed with ramie waste and with plant protein in $\mathrm{CF}_{0} \mathrm{~N}$ and $\mathrm{CF}_{1} \mathrm{~N}$ was $2.08 \pm 0.94 \mathrm{mMol}$ and $23.22 \pm 11.23$ $\mathrm{mMol}$, respectively, or higher than that with animal protein in $\mathrm{CF}_{0} \mathrm{H}$ and $\mathrm{CF}_{1} \mathrm{H}$ namely $1.64 \pm 0.33 \mathrm{mMol}$ and $3.99 \pm 2.76 \mathrm{mMol}$, respectively $(P<0.01)$. Ensilaged complete feed with plant protein showed decreased NDF percentage from $\mathrm{CF}_{0} \mathrm{~N}$ to $\mathrm{CF}_{1} \mathrm{~N}$ greater than $\mathrm{CF}_{0} \mathrm{H}$ to $\mathrm{CF}_{1} \mathrm{H}$. Fiber (NDF) was degraded to $\mathrm{C}_{2}$ so that $\mathrm{C}_{2}$ concentration increased. Fishmeal protein consisted of essential amino acid resistant to ruminal microbe degradation (Dhanda et al., 2003). Acetic acid concentration in cow ruminal fluid given soybean meal was $63.1 \mathrm{~mol} / 100 \mathrm{~mol}$, or higher than that given fishmeal namely $59.3 \mathrm{~mol} / 100 \mathrm{~mol}(\mathrm{P}<0.05)$ (Abu-Ghazaleh et al., 2001).

Interaction between complete feed with ramie waste with and without ensilage, combined with either plant protein and animal Protein decreased crude protein $(C P)(P<0.05)$. $\mathrm{HSD}$ test indicated the difference between $\mathrm{CF}_{1} \mathrm{H}$ 
Table 3. Ensilage parameter of ramie waste-based complete feed (\%DM)

\begin{tabular}{lcccc}
\hline Nutrient & Protein Source & $\mathrm{CF}_{0}$ & \multicolumn{1}{c}{$\mathrm{CF}_{1}$} & Interaction \\
\hline $\mathrm{pH}$ & $\mathrm{N}$ & $5.99 \pm 0.36^{\mathrm{a}}$ & $4.99 \pm 0.36^{\mathrm{b}}$ & $\mathrm{S}$ \\
& $\mathrm{H}$ & $6.77 \pm 0.55^{\mathrm{a}}$ & $4.61 \pm 0.09^{\mathrm{b}}$ & \\
$\mathrm{C}_{2}, \mathrm{mmol}$ & $\mathrm{N}$ & $2.08 \pm 0.94^{\mathrm{ce}}$ & $23.22 \pm 11.23^{\mathrm{de}}$ & $\mathrm{S}$ \\
& $\mathrm{H}$ & $1.64 \pm 0.33^{\mathrm{cf}}$ & $3.99 \pm 2.76^{\mathrm{df}}$ & \\
$\mathrm{C}_{3}, \mathrm{mmol}$ & $\mathrm{N}$ & $15.20 \pm 3.39^{\mathrm{g}}$ & $15.54 \pm 3.03^{\mathrm{h}}$ & $\mathrm{S}$ \\
& $\mathrm{H}$ & $10.77 \pm 3.61^{\mathrm{g}}$ & $26.51 \pm 4.22^{\mathrm{h}}$ & $\mathrm{NS}$ \\
$\mathrm{C}_{4}, \mathrm{mmol}$ & $\mathrm{N}$ & $0.99 \pm 0.05^{\mathrm{h}}$ & $1.64 \pm 0.55^{\mathrm{j}}$ & \\
& $\mathrm{H}$ & $1.01 \pm 0.17^{\mathrm{i}}$ & $2.93 \pm 0.44^{\mathrm{j}}$ & $\mathrm{NS}$ \\
Lactic Acid & $\mathrm{N}$ & $365.09 \pm 101.52^{\mathrm{k}}$ & $1565.38 \pm 551.611^{\mathrm{l}}$ & $\mathrm{N}$ \\
$(\mathrm{mg} / 100 \mathrm{~g})$ & $\mathrm{H}$ & $263.36 \pm 75.56^{\mathrm{k}}$ & $1751.32 \pm 275.48^{\mathrm{l}}$ & $\mathrm{NS}$ \\
$\mathrm{NH}_{3}-\mathrm{N}(\%)$ & $\mathrm{N}$ & $0.031 \pm 0.006^{\mathrm{m}}$ & $0.042 \pm 0.0047^{\mathrm{m}}$ & \\
& $\mathrm{H}$ & $0.038 \pm 0.006^{\mathrm{n}}$ & $0.045 \pm 0.005^{\mathrm{n}}$ & \\
WSC (\%) & $\mathrm{N}$ & $52.95 \pm 2.10^{\mathrm{c}}$ & $49.77 \pm 0.92^{\mathrm{c}}$ & $\mathrm{NS}$ \\
& $\mathrm{H}$ & $49.38 \pm 1.48^{\mathrm{d}}$ & $48.94 \pm 3.74^{\mathrm{d}}$ & \\
\hline
\end{tabular}

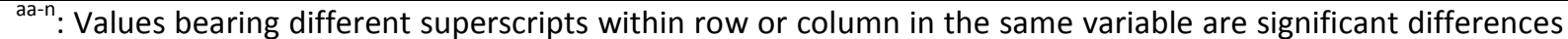
$(\mathrm{P}<0.01) ; \mathrm{C}_{2}$ : acetic acid; $\mathrm{C}_{3}$ : propionic acid; $\mathrm{C}_{4}$ : butyric acid; $\mathrm{CF}_{0}$ : ensilage ramie waste-based complete feed, $\mathrm{CF}_{1}$ : ensilage ramie waste-based complete feed; $\mathrm{N}$ : ramie waste-based complete feed with plant protein; $\mathrm{H}$ : ramie waste-based complete feed with animal protein.

(16.20\%) with $\mathrm{CF}_{0} \mathrm{H}, \mathrm{CF}_{0} \mathrm{~N}$ and $\mathrm{CF}_{1} \mathrm{~N}$, scoring $17.87,18.51$ and $18.83 \%$, respectively.

Interaction among treatments also affected ensilage parameter on $\mathrm{pH}(\mathrm{P}<0.05), \mathrm{C}_{2}$ and $\mathrm{C}_{3}$ $(\mathrm{P}<0.01)$. Interaction of both treatments on $\mathrm{pH}$ was different in $\mathrm{CF}_{0} \mathrm{~N}$ vs $\mathrm{CF}_{0} \mathrm{H}, \mathrm{CF}_{1} \mathrm{~N}$ and $\mathrm{CF}_{1} \mathrm{H}$, and in $\mathrm{CF}_{0} \mathrm{H}$ vs $\mathrm{CF}_{1} \mathrm{~N}$ and $\mathrm{CF}_{1} \mathrm{H}$. Ensilaged complete feed combined with animal protein $\left(\mathrm{CF}_{1} \mathrm{H}\right)$ indicated the lowest $\mathrm{pH}$. The decreased of DM was followed by increased concentration of $C_{2}, C_{3}, C_{4}$ and LA. Fishmeal contained high quality amino acid that supported ensilage process by forming organics acid to reach the lowest $\mathrm{pH}$ of 4.614. Fishmeal contained much protein and excellent amino acid balance (Dhanda et al., 2003). Interaction of both treatment on $C_{2}$ complete feed ramie waste indicated increased effect on $\mathrm{CF}_{1} \mathrm{~N}$ vs $\mathrm{CF}_{0} \mathrm{~N}$; $\mathrm{CF}_{0} \mathrm{H}$ and $\mathrm{CF}_{1} \mathrm{H}$. Nutrient in ensilaged complete feed with plant protein was more available to acetic acid microbe than other complete feed (Tripathi, 2014). Ensilaged complete feed with plant protein showed decreased NDF percentage from $\mathrm{CF}_{0} \mathrm{~N}$ to $\mathrm{CF}_{1} \mathrm{~N}$ greater than $\mathrm{CF}_{0} \mathrm{H}$ to $\mathrm{CF}_{1} \mathrm{H}$. Degradation product of fiber (NDF) produced $C_{2}$ so that $C_{2}$ concentration increased. Interaction of both treatment also significantly affected $C_{3}$. Difference was observed on $\mathrm{CF}_{1} \mathrm{H}$ vs $\mathrm{CF}_{0} \mathrm{~N} ; \mathrm{CF}_{0} \mathrm{H}$ and $\mathrm{CF}_{1} \mathrm{~N}$. Ensilage process in complete feed with ramie waste with animal protein resulted in the highest concentration $\mathrm{C}_{3}$ of all complete feed. The increase of $\mathrm{C}_{3}$ concentration was caused by degradation of WSC concentration of complete feed with ramie waste. The activity of amylolytic bacteria used WSC to produced C3. The concentration of C3 in $P$. purpureum silage was $15.8 \mathrm{mM}$ (Santoso and Hariadi, 2008).

Mold was found in one among 20 treatment units namely $\mathrm{CF}_{1} \mathrm{H}_{1}(5 \%)$, assumedly due to leak in the knot because mold spot only grew in that part. complete feed with ramie waste without ensilage was light brown colored with crumbly texture and fresh aroma (not moldy) while that with ensilage was darker brown, compact texture but acidic smell.

\section{Conclusion}

The used of plant protein in ensilage complete feed with rami waste was better than that with animal protein although both silage were not better due to $\mathrm{pH}$ over 4.5.

\section{References}

Abu-Ghazaleh AA, DJ Schingoethe and AR Hippen. 2001. Blood amino acids and milk composition 
from cows fed soybean meal, fish meal or both. J. Dairy Sci. 84:1174-1181.

AOAC. 1994. Association of Official Agricultural Chemists. Agricultural Chemicals; Contaminants and Drugs. Vol 2. Virginia USA.

Assan N. 2015. Some major factors affecting carcass composition in goats. Sci. J. Anim. Sci. 4(7):81-88.

Contò G, F Carfi and V Pace. 2011. Chemical composition and nutritive value of ramie plant [Boehmeria nivea (I.) gaud] and its by-products from the textile industry as feed for ruminants. J. Agric. Sci. and Tech. A1: 641-646.

Dhanda JS, DG Taylor, PJ Murray, RB Pegg and PJ Shand. 2003. Goat Meat Production: Present Status and Future Possibilities. Asian-Aust. J. Anim. Sci.16(12):1842-1852.

Gabbi AM, J Viégas, GSP Toledo, AL Iora, L Fronza, SB Carlotto. 2004. Increasing Levels of Ramie (Boehmeria nivea) Hay on the Diets Of Fattening Rabbits. In: Proceedings-8th World Rabbit Congress.Sept. 7-10, Puebla, Mexico. p.839-844.

Hartadi H, S Reksohadiprodjo and AD Tillman. 2005. Tabel Komposisi Pakan untuk Indonesia. Gajah Mada University Press. Yogyakarta.

Kung Jr, LJR Robinson, NK Ranjit, JH Chen, CM Golt and CD Pesek. 2000. Microbial populations, fermentation end products and aerobic stability of corn silage treated with ammonia or a propionic acid-based preservative. J. Dairy Sci. 83:1479-1486.

Liu Li-Jun, T Di-Luo, D Xiao-Bing, Y Run-Qing and $P$ Ding-Xiang. 2012. Effect of a new continuous production technology of ramie (boehmeria nivea) on fiber yield and fineness. Int J Agric. Biol. 14(1):87-90

Nadeau EM, GDR Buxton, JR Russel, Mj Allison and JW Young. 2000. Enzyme, bacterial inoculant and formic acid effects on silage composition of orchard grass and alfalfa. J. Dairy Sci. 83:14871492.

Nigam A and A Ayyagari. 2007. Lab Manual in Biochemistry, Immonology and Biotechnology. Tata McGraw Hill Education Private Limited. New Delhi.

Owen VN, KA Albrecht and RE Muck. 2002. Protein degradation and fermentation characteristics of unwilted red clover and alfafa silage harvested at various times during the day. Grass Forage Sci. 57:329-341.

Santoso B and BTj Hariadi. 2008. The chemical composition, in vitro nutrient degradation and methane gas production of tropical grasses preserved with silage and hay methods. Media Peternakan 31(2):128-137.

Santoso B, MN Lekitoo and Umiyati. 2007. Chemical compositions and nutrient degradation of
Elephant grass silage ensiled with black tea waste. Animal Production. 9(3):160-165.

Shao T, ZX Zhang, M Shimojo, T Wang and Y Masuda. 2005. Comparison of fermentation characteristics of Italian ryegrass (Lolium multiflorum Lam.) and guineagrass (Panicum maximum Jacq.) during the early stage of ensiling. Asian-Austr. J. Anim. Sci. 18:1727-1734.

Sharifi M, M Bashtani, AA Naserian, H Khorasan. 2013. Effect of dietary crude protein level on the performance and apparent digestibility of Iranian Saanen kids. African J Biotec. 12(26):4202-4205.

Steel RGD and JH Torrie. 1993. Principles and Procedures of Statistics. Mc Graw-Hill Book Co. Inc. Pub. Ltd. London.

Subandi M. 2012. The Effect of Fertilizers on the Growth and the Yield of Ramie (Boehmeria nivea L. Gaud). Asian J. Agric. Rural Dev. 2(2):126-135.

Tisch DA. 2006. Animal Feed, Feeding and Nutrition, and Ration Evaluation with CD-ROM. Delmar Cengage Learning. NY USA.

Tripathi MK.2014. Effect of Nutrition on Production, Composition, Fatty acids and Nutraceutical Properties of Milk. J Adv Dairy Res 2:115.

Vasupen K, C Yuangklang, S Witayakun and Srinanuan. 2005. Effect of Difference Moisture on Quality of Fermented Total Mixed Ration. In: Proceeding of the Technical Conference of 43th Kasetsart University, Bangkok.

Vasupen K, C Yuangklang, C Sarnklong, S Wongsuthavas, J Matchaothai and P Srenanul. 2006. Effects of total mixed ration and fermented total mixed ration on voluntary feed intake, digestion nutrition digestibility and milk production in lactating dairy cows. In: Proceedings of the Technical Conference of 44th. Kasetsart University, Bangkok.

Wang J, JQ Wang, DP Bu, WJ Guo, ZT Song and JY Zhang. 2010. Effect of storing total mixed rations anaerobically in bales on feed quality. Anim. Feed Sci.Tech. 161:94-102.

Wongnen C, C Wachirapakorn, C Patipan, D Panpong, K Kongweha, N Namsaen, P Gunun and C Yuangklang. 2009. Effects of fermented total mixed ration and cracked cottonseed on milk yield and milk composition in dairy cows. AsianAust. J. Anim. Sci. 22(12):1625-1632..

Yongsheng C, G Wang, H Wang, C Cheng, G Zang, X Guo and R H. Liu. 2014. Phytochemical Profiles and Antioxidant Activities in Six Species of Ramie Leaves.Plos One. 9(9):1-6.

Zhao XH, T Zhang, M Xu, JH Yao. 2011. Effects of physically effective fiber on chewing activity, ruminal fermentation, and digestibility in goats. J Anim Sci. 89(2):501-509. 